\title{
KEEFEKTIFAN MODEL PROBLEM BASED LEARNING (PBL) DENGAN MEDIA DAKOTA TERHADAP HASIL BELAJAR MATERI FPB DAN KPK
}

\author{
Mei Riska Dwi Ariyanti ${ }^{1}$, Rasiman ${ }^{2}$, Mei Fita Asri Untari ${ }^{3}$ \\ ${ }^{1,2,3}$ Pendidikan Guru Sekolah Dasar, Fakultas IImu Pendidikan,Universitas PGRI Semarang \\ email : Meiriska2405@gmail.com
}

\begin{abstract}
ABSTRAK
Peneliti ini bertujuan untuk mengidentifikasi efektif atau tidaknya model pembelajaran Problem Based Learning dengan media DAKOTA terhadap hasil belajar materi FPB dan KPK siswa kelas IV SD Negeri Banyubiru 01 Kabupaten Semarang. Penelitian ini merupakan penelitian ekperimen jenis kuantitatif. Penelitian ini menggunakan One Group Pretest-Posttest Design. Populasi dalam penelitian ini adalah semua peserta didik kelas IV SD Negeri Banyubiru 01 Kabupaten Semarang berjumlah 39 siswa tahun ajaran 2018/2019. Intrumen yang digunakan adalah (1) wawancara untuk mendapatkan informasi tentang kondisi awal siswa serta materi yang akan diajarkan. (2) Dokumentasi mendapatkan dokumen sekolah mengenai nama siswa, jumlah siswa, dan data-data yang diperlukan dalam penelitian daftar nilai, daftar nama siswa dan dokumen pelaksanaan kegiatan pembelajaran selama penelitian. (3) tes untuk mengukur ini untuk mengukur hasil belajar siswa aspek kognitif. Analisis Data menggunakan Teknis analisis data peneliti menggunakan uji normalitas, uji homogenitas dan uji hipotesis (uji-t). Uji normalitas digunakan untuk mengetahui kelas tersebut berdistribusi normal atau tidak. Uji Homogenitas Untuk menguji homogenitas varians dari dua kelompok data Uji hipotesis menggunakan uji t-test. Hasil penelitian yang dilakukan dapat disimpulkan bahwa model pembelajaran Problem Based Learning dengan media DAKOTA efektif terhadap hasil belajar materi FPB dan KPK kelas IV SDN Banyubiru 01 Kabupaten Semarang. Hal ini dapat dilihat dari rata-rata hasil postest lebih tinggi dari pada pretest selain itu diperkuat dengan hasil perhitungan uji t diperoleh thitung untuk hasil belajar sebesar 14,999 dan dan ttabel sebesar 1,684 karena thitung $(14,999)>$ ttabel $(1,684)$ maka hal ini menunjukkan bahwa uji t hasil belajar signifikan.
\end{abstract}

Kata Kunci : Problem Based Learning, DAKOTA, Hasil Belajar, Matematika

\section{ABSTRACT}

The researcher aims to identify the effectiveness of the Problem Based Learning model with DAKOTA media on the learning outcomes of FPB and KPK material for fourth grade students of SD Negeri Banyubiru 01 Semarang Regency. This research is a quantitative type of research. This study uses One Group Pretest-Posttest Design. The population in this study were all fourth grade students of SD Negeri Banyubiru 01 Semarang Regency totaling 39 students in the 2018/2019 academic year. The instruments used are (1) interviews to get information about the students' initial conditions and the material to be taught. (2) Documentation of obtaining school documents regarding student names, number of students, and data needed in the value list research, student rosters and documents on the implementation of learning activities during the research. (3) tests to measure this to measure student learning outcomes on cognitive aspects. Data Analysis using Technical data analysis researchers used the normality test, homogeneity test and hypothesis test (t-test). The normality test is used to find out whether the class is normally distributed or not. Homogeneity Test To test the variance homogeneity of two groups of data Hypothesis testing uses the t-test. The results of the research conducted can be concluded that the Problem Based Learning model with DAKOTA media is effective against the learning outcomes of the fourth grade FPB and KPK material at the Banyubiru 01 Elementary School in Semarang Regency. This can be seen from the average posttest results higher than the pretest, but it is also reinforced by the results of $t$ test calculations obtained by tcount for learning outcomes of 14.999 and ttable of 1.684 because tcount (14.999)> ttable (1.684) then this indicates that test significant learning outcomes.

Kata Kunci : Problem Based Learning, DAKOTA, Hasil Belajar, Matematika 


\section{Pendahuluan}

Pendidikan nasional berfungsi mengembangkan kemampuan dan membentuk watak serta peradapan bangsa yang bermartabat dalam rangka mencerdaskan kehidupan bangsa. Pendidikan Nasional bertujuan untuk mengembangkan potensi peserta didik agar menjadi manusia yang beriman dan bertaqwa kepada Tuhan Yang Maha Esa, berakhlak mulia, sehat, berilmu, kreatif, mandiri, dan menjadi warga negara yang demokratis serta tanggung jawab (UU No. 20 Tahun 2003 tentang Sisdiknas).

Peningkatan mutu pendidikan diperlukan adanya perubahan pola pikir yang digunakan sebagai landasan pelaksanaan kurikulum. Kurikulum adalah separangkat rencana dan pengaturan mengenai tujuan, isi dan bahan pelajaran serta cara yang digunakan sebagai pedoman penyelenggaraan kegiatan pembelajaran untuk mencapai tujuan pendidikan tertentu (UU No. 20 Tahun 2003 tentang Sisdiknas). Pada saat ini, kurikulum yang berlaku di Indonesia yaitu kurikulum 2013.

Kurikulum 2013 adalah kurikulum berbasis kompetensi yang dirancang untuk mengantisipasi kebutuhan kompetensi abad 21. Dalam kurikulum 2013 untuk SD/MI pembelajarannya tematik terpadu. Menurut Depdikbud (1990) pembelajaran terpadu/pembelajaran terintegrasi atau intregated learning merupakan suatu model pembelajaran yang mencoba memadukan beberapa pokok bahasan atau bidang studi atau berbagai materi dalam satu sajian pembelajaran (Daryanto, 2014 : 42). Dalam pembelajaran tematik terpadu memadukan atau menintegrasikan berbagai kompetensi dari berbagai mata pelajaran ke dalam berbagai tema. Pengintegrasian tersebut dilakukan dalam dua hal yaitu integrasi sikap, keterampilan dan pengetahuan dalam kaitannya dengan proses pembelajaran dan integrasi berbagai konsep dasar berkaitan. Tema merajut makna berbagai konsep dasar sehingga peserta didik tidak belajar konsep dasar secara parsial. Dengan demikian pembelajarannya memberikan makna yang utuh kepada peserta didik seperti halnya tercemin pada tiap-tiap tema. Tema tersebut juga dapat mempersatukan indicator dari beberapa mata pelajaran seperti Bahasa Indonesia, IPA, IPS, PPKn dan Seni Budaya. Untuk mata pelajaran Agama, Penjasorkes dan Matematika berdiri sendiri atau tidak terintegrasi dengan mata pelajaran lainnya. Salah satu mata pelajaran yang dianggap penting yaitu mata pelajaran matematika.

Beth \& Piaget (1956) mengatakan bahwa yang dimaksud dengan matematika adalah pengetahuan yang berkaitan dengan berbagai struktur abstrak dan hubungan antar-struktur tersebut sehingga terorganisasi dengan baik. Sementara Kline (1972) lebih cenderung mengatakan bahwa matematika adalah pengetahuan yang tidak berdiri sendiri, tetapi dapat membantu manusia untuk memahami dan memecahkan masalah sosial, ekonomi dan alam.(Runtukahu \& Kaldou, 2016:28). Siswa belum mampu berfikir formal maka dalam pembelajaran matematika sangat diharapkan bagi pendidik untuk mengaitkan proses belajar dengan permasalahan yang konkret.

Berdasarkan definisi diatas guru sangat berperan penting dalam pengetahuan dan mengikuti perkembangan zaman diera globalisasi ini, sebab semakin perkembangnya zaman peserta didik akan lebih kritis dengan pengetahuan yang mereka temukan diluar sana untuk menciptakan suasana kelas yang kondusif dan menciptakan sistem pembelajaran yang menumbuhkan rasa cinta mereka terhadap suatu mata pelajaran itu sulit dilakukan. Hal itu terjadi karena pembelajaran yang digunakan guru cenderung menggunakan metode ceramah, hal tersebutlah yang mengakibatkan mereka beranggapan bahwa matematika sulit dipelajari, serta gurunya kebanyakan tidak menyenangkan, membosankan, menakutkan, angker, killer dan sebagainya. Anggapan ini menyebabkan mereka semakin takut untuk belajar matematika sikap ini tentu saja mengakibatkan hasil belajar matematika mereka semakin rendah.

Berkaitan dengan masalah tersebut, peneliti melakukan observasi di SD Negeri Banyubiru 01 Kabupaten Semarang pada kenyataannya proses pembelajaran belum efektif dikarenakan siswa masih pasif dalam menerima materi dan hanya diberikan tugas tugas saja sehingga siswa masih banyak mengobrol dengan teman, tidak fokus dan berlari dari tempat 
duduknya. Di sekolah tersebut penelitiu menemukan suatu masalah yang berkenaan dengan proses belajar mengajar yaitu kurangnya pemahaman siswa dalam memahami konsep-konsep matematika dikarenakan guru hanya memberi infomasi kesiswa dan guru hanya sebagai fasilitator sehingga siswa pasif dalam mencari dan menyelesaikan masalah.

Berdasarkan hasil observasi di SD Negeri SD Negeri Banyubiru 01 Kabupaten Semarang khususnya di kelas IV hasil belajar siswa masih banyak yang mendapat nilai dibawah KKM yaitu 75. Dengan demikian masih perlu untuk dibenahi. Hasil observasi yang dilakukan, guru menggunakan model secara langsung sehingga hasil belajar siswa kurang karena siswa kurang aktif dalam proses pembelajaran. Guru masih menggunakan metode ceramah sehingga kurang menyenangkan dan siswa kurang berantusias dalam belajar. Selain itu penggunaan media dan bahan ajar kurang maksimal. Dalam pembelajaran siswa hanya diberikan materi, tugas-tugas dan PR oleh guru sehingga siswa kurang antusias dalam proses pembelajaran dan siswa belum bisa menguasai secara maksimal. Berdasarkan wawancara pada tanggal 01 September 2018 yang di lakukan dapat dikatakan bahwa factor utama yang menjadi penyebab rendahnya hasil belajar siswa hanya pasif, kurang berfikir kritis dan hanya menerima informasi dan tugas sehingga hanya menghafal. Tidak diajarkan untuk memecahkan masalah dan berfikir kritis sehingga diperlukan model pembelajaran yqang diperlukan siswa untuk berfikir kritis.

Permasalahan yang muncul dari hasil wawancara di SD Negeri Banyubiru 01 Kabupaten Semarang yaitu penggunaan model pembelajaran dan media pembelajaran belum sesuai sehingga siswa belum terlatih untuk berfikir secara kritis dan aktif dalam memecahkan masalah, khususnya pada materi FPB dan KPK guru hanya mengajarkan dengan cara-cara yang sudah ada sebelumnya, ini mengakibatkan siswa kurang memahami materi yang diajarkan oleh guru dengan baik serta tidak adanya interaksi antar siswa selam proses pembelajaran. Oleh karena itu, peneliti bermaksud akan melakukan penelitian menggunakan model pembelajaran yang membiasakan atau mengajarkan siswa dalam memecahkan masalah dan berfikir secara aktif, kreatif dan inovatif yaitu dengan model Problem Based Learning dengan media DAKOTA untuk meningkatkan hasil belajar siswa.

Problem Based Learning (PBL) merupakan pembelajaran uang penyampaiannya dilakukan dengan cara menyajikan suatu permasalahan, mengajukan pertanyaan-pertanyaan, memfasilitasi penyelidikan, dan membuka dialog (Ridwan, 2014:127). Menurut Barrow dalam (Huda,2013:271) Pembelajaran Berbasis-Masalah (Problem Based Learning/PBL) sebagai pembelajaran yang diperoleh melalui proses menuju pemahaman akan revolusi suatu masalah. Masalah tersebut dipertemukan pertama-tama dalam proses pembelajaran. Jadi, fokusnya adalah pada pembelajaran siswa dan bukan pada pengajaran guru.

Menurut Kurniati dalam kompasiana (2015) DAKOTA (Dakon Matematika) adalah suatu media visual dalam pembelajaran matematika yang merupakan inovasi baru sebagai media pembelajaran matematika. Menurut Sundayana (2015) kegunaan Dakota yaitu untuk menentukan faktor persekutuan terkecil (KPK). Jadi, dapat disimpulkan bahwa Dakota merupakan media pembelajaran yang dihasilkan dari penggabungan permainan tradisional dan pembelajaran matematika yang berguna untuk menentukan FPB dan KPK.

Penelitian yang relevan berkaitan dengan penggunaan model Problem Based Learning ini adalah penelitian yang dilakukan oleh Anggun Puspita Sari dengan judul penelitian "Pengaruh Model Problem Based Learning Berbantu Media Tangram terhadap Hasil Belajar Matematika Siswa Kelas IV SDN 01 Undaan Kidul Kudus". Tujuan dalam penelitian ini adalah untuk mengetahui ada pengaruh model Problem Based Learning berbantu media tangram terhadap hasil belajar matematika siswa kelas IV SDN 01 Undaan Kidul Kudus. Dengan demikian dapat disimpulkan bahwa ada pengaruh model Problem Based Learning kolaborasi media Tangram terhadap hasil belajar siswa.

Berdasarkan uraian di atas, maka penulis akan melakukan penelitian dengan judul "Keefektifan model Problem Based Learning (PBL) dengan Media DAKOTA Terhadap Hasil Belajar Materi FPB dan KPK Kelas IV SD Negeri Banyubiru 01 Kabupaten Semarang".

Berdasarkan latar belakang masalah yang telah dikemukakan diatas, dapat mengidentifikasi masalah sebagai berikut : 1. Penggunaan model pembelajaran yang 
digunakan belum optimal karena siswa belum dilatih untuk memecahkan masalah dan hanya pasif dalam menerima materi sehingga hasil belajar kurang optimal, 2) Metode pembelajaran yang digunakan guru hanya penugasan sehingga siswa hanya mengerjakan materi belum biasa berfikir kritis dan hasil belajar kurang optimal 3) Media yang digunakan guru hanya berupa papan tulis dan buku guru sehingga hasul belajar siswa kurang optimal, 4. Bahan ajar yang digunakan guru hanya berpatokan pada buku sehingga referensi siswa kurang mengakibatkan hasil belajar yang optimal.

Berdasarkan latar belakang dan identifikasi masalah yang ada maka peneliti melakukan pembatasan masalah supaya hasil yang diperoleh sesuai dengan yang diharapkan. Permasalah yang dikaji adalah keefektifan model Problem Based Learning dengan media DAKOTA terhadap hasil belajar materi FPB dan KPK siswa kelas IV SD Negeri Banyubiru 01 Kabupaten Semarang.

Berdasarkan Identifikasi masalah dan pembatasan masalah di atas, maka dapat dirumuskan masalah sebagai berikut : apakah model Problem Based Learning dengan media DAKOTA efektif terhadap hasil belajar materi FPB dan KPK siswa kelas IV SD Negeri Banyubiru 01 Kabupaten Semarang?. Tujuan Penelitian ini adalah untuk mengidentifikasi efektif atau tidaknya model pembelajaran Problem Based Learning dengan media DAKOTA terhadap hasil belajar materi FPB dan KPK siswa kelas IV SD Negeri Banyubiru 01 Kabupaten Semarang.

\section{Metode}

Penelitian ini merupakan penelitian ekperimen jenis kuantitatif. Penelitian ini menggunakan One Group Pretest-Posttest Design. Penelitian dilaksanakan di SD Negeri Banyubiru 01 Kabupaten Semarang pada tanggal 19- 22 November 2018 pada tahun ajaran 2018/2019 semester ganjil pada siswa kelas IV SD Negeri Banyubiru 01 Kabupaten Semarang Tahun pelajaran 2018/2019.

Populasi dalam penelitian ini adalah semua peserta didik kelas IV SD Negeri Banyubiru 01 Kabupaten Semarang berjumlah 39 siswa tahun ajaran 2018/2019

Desain ekperimen yang digunakan adalah One Group Pretest-Posttest Design. Rancangan ini menggunakan control minimal, dengan gambar sebagai berikut.

\begin{tabular}{|lll|}
\hline$T_{1}$ & $\mathrm{X}$ & $T_{2}$ \\
\hline
\end{tabular}

(Soegeng, 2006: 163)

Keterangan :

\section{Gambar 1. One Group Pretest - Posttest Design}

T1 : Tes awal ( sebelum diberi perlakuan model pembelajaran Problem Based Learning) T2 : Tes Akhir ( setelah diberi perlakuan model pembelajaran Problem Based Learning) $X$ : Perlakuan model pembelajaran pembelajaran Problem Based Learning

Teknik pengumpulan data dalam penelitian ini adalah wawancara, dokumentasi dan tes. Wawancara bertujuan untuk mendapatkan informasi tentang kondisi awal siswa serta materi yang akan diajarkan. Dokumentasi dalam penelitian ini digunakan untuk mendapatkan dokumen sekolah mengenai nama siswa, jumlah siswa, dan data-data yang diperlukan dalam penelitian. Metode dokumentasi digunakan untuk daftar nilai, daftar nama siswa dan dokumen pelaksanaan kegiatan pembelajaran selama penelitian.

Metode tes ini digunakan peneliti ini untuk mengukur hasil belajar siswa baik yang tidak menggunakan media maupun pembelajaran yang menggunakan model Problem Based Learning.Metode tes yang digunakan penelitian ini adalah :(1) Pre Test merupakan langkah awal untuk mengetahui kemampuan awal siswa mengenai pembelajaran yang disampaikan. (2) 
Post Test merupakan uji ekperimen yaitu test yang dilaksanakan setelah ekperimen dilaksanakan. Tujuan post test adalah untuk mendapatkan nilai sampel setelah diberi perlakuan. Peserta didik dikatakan berhasil mencapai hasil belajar jika nilainya diatas KKM, yaitu > 75. Selain itu penilaian hasil belajar juga dapat dikategorikan menjadi 4 indikator diantaranya adalah Baik Sekali, Baik, Cukup, dan kurang. Pengembangan instrumen tes terdiri dari beberapa tahapan, yaitu: (1) mengkaji silabus mata pelajaran Matematika kelas IV SD; (2) menyusun kisi-kisi tes didasarkan pada teori yang dikembangkan oleh Bloom; (3) menulis butir soal; (4) menelaah butir soal; (5) melakukan uji coba; dan (6) menganalisis butir soal.

Setelah proses validasi berdasarkan pendapat ahli dilakukan, instrumen diujicobakan pada siswa kelas IV SD yang memiliki karakteristik yang hampir sama dengan siswa yang menjadi subjek penelitian ini. Sekolah yang dipilih sebagai tempat uji coba instrumen adalah SD Banyubiru 05 Kabupaten Semarang

Teknis analisis data peneliti menggunakan uji normalitas, uji homogenitas dan uji hipotesis (uji-t). Uji normalitas digunakan untuk mengetahui kelas tersebut berdistribusi normal atau tidak. Uji Homogenitas Untuk menguji homogenitas varians dari dua kelompok data. Rumus uji homogenitas varians yang digunakan yaitu rumus uji F. Adapun rumus Uji F adalah sebagai berikut :

$$
\text { Fhitung }=\frac{\text { Varian } \text { Terbesar }}{\text { Varian Terkeci }}
$$

Kriteria pengujian untuk mengetahui data yang mempunyai varians yang homogeny yaitu, jika $F_{\text {hitung }}>F_{\text {tabel }}$ maka sampel homogeny. Pengujian dilakukan pada taraf signifikan 5\% dengan derajat kebebasan untuk pembilang $n_{1}-1$ dan kebebasan untuk penyebut $n_{2}-1$. Data yang telah diuji normalitas dan homogenitasnya selanjutnya dilakukan uji hipotesis. Adapun hipotesis penelitian yang akan diuji yaitu sebagai berikut:

Ho :Tidak terdapat perbedaan nilai hasil belajar yang lebih baik antara sebelum (pretest) dan sesudah (post-test) menggunakan model Problem Based Learning dengan media DAKOTA

$$
t=\frac{\bar{d}-0}{\frac{s}{\sqrt{n}}} \text { dimana } s=\sqrt{\frac{(d-\bar{d})^{2}}{n}}
$$

Keterangan:

$\mathrm{t}$ : Perbedaan rata-rata prestasi belajar

$s$ : Simpangan baku gabungan

d : Selisih kedua pengukuran

$\bar{d}$ : rataan kedua pengukuran

$\mathrm{n}$ : jumlah sampel

Kriteria pengujian adalah : Ha diterima jika $t_{\text {hitung }}>t_{\text {tabel}}$, dengan $d k=\left(n_{1}+n_{2}-2\right)$ dan peluang $\left(1-\frac{1}{2} a\right)$. Untuk harga t lainnya ditolak.

\section{Hasil Dan Pembahasan}

Pada penelitian ini subyek dikenakan dua kali pengukuran, yang pertama sebelum kegiatan dengan menggunakan model pembelajaran Problem Based Learning, siswa diberikan soal Pretest, dan yang kedua setelah kegiatan dengan menggunakan model pembelajaran Problem Based Learning, siswa diberikan soal Posttest. Peneliti mengambil satu kelas sebagai sampel penelitian. Pengambilan sampel ini didasarkan pada kelas yang berdistribusi normal.

Data hasil uji coba normalitas awal menggunakan uji liliefors untuk nilai hasil pretest yang hasilnya didapatkan bahwa $\mathrm{L}_{0}$ hasil belajar $(0,0913)<\mathrm{L}_{\text {tabel }}(0,142)$ maka $\mathrm{H}_{\mathrm{o}}$ diterima, 
sehingga sampel berasal dari populasi tersebut berdistribusi normal. Dari data uji normalitas menggunakan uji liliefors untuk nilai hasil posttest memenuhi kriteria pengujian yaitu $L_{0}<L_{\text {tabel }}$, hal ini menunjukkan bahwa sampel hasil posttest berdistribusi normal. Untuk mengetahui apakah model pembelajaran Problem Based Learning dengan media DAKOTA efektif terhadap hasil belajar materi FPB dan KPK kelas IV SD N Banyubiru 01 Kabupaten Semarang ini dilakukan analisis tahap akhir berupa uji t. Hasil analisis data akhir untuk pengujian hipotesis pada hasil belajar pretest dan posttest kelas eksperimen didapatkan $t_{\text {hitung }}(14,999)>t_{\text {tabel }}$ $(1,684)$ untuk nilai hasil belajar, dimana menunjukkan bahwa $t_{\text {hitung }}$ berada pada daerah penerimaan $\mathrm{H}_{a}$. Hal ini menunjukkan bahwa apakah model pembelajaran Problem Based Learning dengan media DAKOTA efektif terhadap hasil belajar materi FPB dan KPK kelas IV SD N Banyubiru 01 Kabupaten Semarang.

Tabel 1. Daftar nilai hasil penelitian hasil belajar peserta didik

\begin{tabular}{lcc}
\multicolumn{1}{c}{ Keterangan } & \multicolumn{2}{c}{ Hasil Belajar } \\
& Pretest & Posttest \\
\hline Jumlah peserta didik & 6 & 34 \\
Peserta didik Tuntas & 33 & 5 \\
Peserta didik Tidak Tuntas & 57,56 & 86,79 \\
Rata-rata & \multicolumn{2}{c}{$29,23 \%$} \\
Persentase Kenaikan & \multicolumn{2}{c}{ Sumber: Analisis Hasil Penelitian } \\
\hline
\end{tabular}

Setelah dilakukan penelitian dengan menggunakan model pembelajaran Problem Based Learning dengan media DAKOTA terkumpul berbagai data seperti rata-rata nilai hasil belajar pretest dan posttest. Pada rata-rata nilai hasil belajar sebelum diberi pembelajaran Problem Based Learning dengan media DAKOTA adalah 57,56. Sebanyak 6 siswa yang tuntas dan 33 siswa yang tidak tutas. Setelah diberi perlakuan dengan model pembelajaran Problem Based Learning dengan media DAKOTA nilai rata-rata posttest adalah 86,79 dengan persentase kenaikan sebesar $26,23 \%$. Sebanyak 34 siswa tuntas dan 5 siswa yang tidak tuntas. Meningkatnya nilai rata-rata hasil belajar siswa dikarenakan perhatian siswa dalam proses pembelajaran sangat tinggi yang dimana pada proses pembelajaran menggunakan model pembelajaran Problem Based Learning dengan media DAKOTA. Hal tersebut dapat dilihat pada gambar diagram di bawah ini :

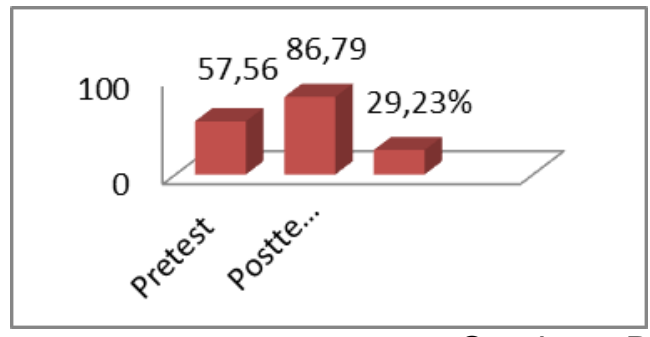

Sumber : Data Hasil Penelitian (2018)

Gambar 2. Diagram Data Hasil Penelitian

Beberapa faktor yang menyebabkan pembelajaran pada kelas eksperimen hasil belajar efektif dikarenakan dalam proses pembelajaran siswa terlihat lebih aktif dalam membangun pengetahuannya sendiri melalui serangkaian tugas baik secara individu maupun secara kelompok, sehingga pengetahuan tersebut akan lebih lama dalam memorinya. Dengan model pembelajaran Problem Based Learning dengan media DAKOTA juga dapat termotivasi untuk 
lebih berfikir kritis dalam memahami konsep untuk mencapai hasil belajar yang optimal dan berlomba-lomba untuk mendapatkan nilai yang lebih dari kelompok lain, sehingga meningkatkan keterampilan dalam menyelasaikan masalah. Hasil belajar yang maksimal juga disebabkan oleh pelaksanan pembelajaran yang sudah sesuai sintak model pembelajaran Problem Based Learning.

Pada pelaksanaan proses penelitian ini terdapat beberapa kekurangan diantaranya adalah masih ada beberapa siswa yang ramai sendiri atau mengobrol dengan temannya dan tidak berdiskusi pada saat pembelajaran berlangsung. Selain itu, model pembelajaran Problem Based Learning membutuhkan waktu yang lama, karena tidak semua siswa mengeluarkan pendapat, ketidakseriusan siswa pada saat mengerjakan tes kemampuan awal, sarana dan prasarana kurang mendukung. Sehingga peningkatan hasil belajar sebanyak $29,23 \%$. Terlepas dari kekurangan yang ada, pada penelitian ini dengan adanya peningkata hasil belajar siswa juga mengalami peningkatan. Aktivitas siswa mengalami peningkatan sehingga berdampak pada hasil belajar siswa yang memuaskan. Setelah dilakukan perhitungan uji hipotesis yang telah dipaparkan pada analisis data akhir diperoleh kesimpulan sebagai hasil penelitian ini menyatakan bahwa model pembelajaran Problem Based Learning dengan media DAKOTA efektif terhadap hasil belajar materi FPB dan KPK kelas IV SD N Banyubiru 01 Semarang.

Ketuntasan belajar individual dinyatakan sudah tercapai apabila peserta didik telah menguasai sekurang-kurangnya $75 \%$ terhadap materi setiap bahasan yang diajukan. Ketuntasan belajar klasikal $75 \%$ dari jumlah peserta didik secara keseluruhan mencapai KKM. Berikut tabel ketuntasan belajar peserta didik:

Tabel 2. Tingkat Ketuntasan hasil Belajar

\begin{tabular}{ccccc}
\hline NO & Hasil Belajar & Tingkat Ketuntasan Minimal & \multicolumn{2}{c}{ persentase } \\
& & & Tuntas & Tidak Tuntas \\
\hline 1 & Pretest & $75 \%$ & $615,38 \%$ & $3384,62 \%$ \\
2 & Posttest & $75 \%$ & $3481,18 \%$ & $512,82 \%$ \\
\hline & & & \multicolumn{2}{c}{ Sumber : Data Hasil Penelitian $(2018)$}
\end{tabular}

Ketuntasan belajar peserta didik secara individu dan klasikal mengalami peningkatan. Dapat dilihat dari data hasil belajar post-test lebih baik daripada pretest. Hal ini dibuktikan dengan perolehan nilai peserta didik yang telah mencapai KKM lebih dari 50\%. Faktor yang mempengaruhi ketuntasan hasil belajar peserta didik diantaranya pemahaman konsep materi yang diperoleh peserta didik. Dalam aspek pengetahuan terkait dengan materi tetang FPB dan KPK, peserta didik paham akan konsep Faktorisasi dan kelipatan yang dijelaskan, peserta didik juga mampu bepikir kritis dalam mengerjkan soal-soal yang berkaitan dengan pemecahan masalah sehari-hari yang berkaitan dengan FPB dan KPK Dilihat dari perolehan nilai post-test yang meningkat, aspek ketrampilan yang menjadikan peserta didik pasif menjadi aktif dan aspek sikap yang menjadikan peserta didik mampu berpikir kritis untuk memecahkan masalah secara berama-sama, maka diperoleh hasil ketuntasan peserta didik yang meningkat. Sebelum diberikan perlakuan (pretest) hanya ada beberapa peserta didik saja yang tuntas, sedangkan setelah diberikan perlakuan (post-test) sebagian besar peserta didik mendapatkan nilai tuntas. Jadi dapat disimpulkan bahwa ketuntasan belajar peserta didik meningkat setelah diberikan perlakuan menggunakan model Problem Based Learning dengan media DAKOTA.

Keterkaitan dengan teori belajar berdasarkan data hasil penelitian model Problem Based Learning dapat membantu peserta didik belajar melalui upaya penyelesaian permasalahan dunia nyata (real word problem) secara terstruktur untuk mengkontruksi pengetahuan peserta didik. Dalam model Problem Based Learning menuntut peserta didik untuk aktif melakukan penyelidikan dalam penyelesaian masalah dan guru berperan sebagai fasilitator atau pembimbing hal ini sesuai dengan teori belajar kontruktivisme. Teori Kontruktivisme yang dipelopori oleh Jean Piaget menegaskan bahwa pengetahuan dibangun dalam pikiran anak melalui akomodasi dan asimilasi. Piaget menegaskan bahwa penekan teori 
kontruvisme pada proses belajar pengetahuan dari realita lapangan. Peran guru dalam pembelajaran menurut teori kontruvisme adalah sebagai fasilitator atau moderator. Kelebihan dari model Problem Based Learning yaitu dapat meningkatkan kemampuan berfikir kritis, menumbuhkan inisiatif peserta didik dalam bekerja, memotivasi internal untuk belajar. Selain itu, kelemahan dari model Problem Based Learning yaitu jika peserta didik mempunyai kepercayaan bahwa masalah yang dipelajari sulit dipecahkan, maka peserta didik enggan mencoba. Model pembelajaran Problem Based Learning dapat di terapkan di kelas IV SD karena berdasarkan teori piaget kelas 4 berada pada operasi konkret. Pada usia tersebut peserta didik telah memahami operasi logis seperti pada pembelajaran matematika dengan bantuan benda-benda konkret sebagai media. Berdasarkan teori piaget Problem Based Learning dilakukan dengan cara menyajikan suatu masalah yang bersifat nyata, untuk itu model Problem Based Learning cocok digunakan untuk kelas IV SD.

Penerapan model pembelajaran Problem Based Learning dengan media DAKOTA ini telah terbukti meningkatkan hasil belajar peserta didik. Pada proses pembelajaran peserta didik dapat memecahkan atau menyelesaikan permasalahan sehari-hari yang berkaitan dengan FPB dan KPK dan membentuk kemampuan berfikir tingkat tinggi (Higher order thinking) dan berfikir kritis. Hal ini sejalan dengan pendapat Rusman dalam Fathurrahman (2017: 112) Problem Based Learning adalah pembelajaran yang menggunakan masalah nyata (autentik) yang tidak terstuktur dan bersifat terbuka sebagai konteks bagi peserta didik untuk membangun keterampilan menyelesaian masalah dan berfikir kritis serta sekaligus membangun pengetahuan baru. Sedangkan untuk kelemahan model Problem Based Learning jika peserta didik mempunyai kepercayaan bahwa masalah yang dipelajari sulit dipecahkan, maka peserta didik enggan mencoba. Peneliti setuju karena pada waktu berdiskusi dengan kelompok masih banyak peserta didik yang masih enggan mencoba menyelesaikan soal pemecahan masalah mengenai FPB dan KPK.

Keberhasil model Problem Based Learning juga dilengkapi dengan media DAKOTA. Media DAKOTA digunakan untuk menjelaskan konsep FPB dan KPK, dengan adanya media DAKOTA dalam aspek pengetahuan peserta didik paham akan konsep Faktorisasi dan kelipatan yang dijelaskan, peserta didik juga mampu bepikir kritis dalam mengerjkan soalsoal yang berkaitan dengan pemecahan masalah sehari-hari yang berkaitan dengan FPB dan KPK. Apabila penanaman konsep ditanamkan baik pada diri peserta didik, maka peserta didik akan paham dengan materi yang disampaikan. Ketrampilan peserta didik dalam menggunakan media DAKOTA juga baik, para peserta didik mampu menggunakan media dengan terampil. Sedangkan dalam aspek sikap, seperti saat diskusi kelompok peserta didik berpikir kritis dan tekun dalam menyelesaikan soal-soal yang diberikan.

Keberhasilan model Problem Based Learning dapat dilihat melalui sintaks model Problem Based Learning yang telah tercapai, yaitu:

a. Tahap I (Mengorientasi peserta didik terhadap masalah)

Pada tahap I ini terbukti berhasil, guru dapat memotivasi peserta didik untuk terlibat aktif dalam pemecahan masalah melalui media DAKOTA untuk menjelaskan konsep FPB dan KPK.

b. Tahap II (Mengorganisasi peserta didik untuk belajar)

Pada tahap II ini terbukti berhasil, guru dapat membantu peserta didik mendifinisikan dan mengorganisasi tugas belajar yang berhubungan dengan masalah yang sudah diorientasikan pada tahap sebelumnya. Pada tahap ini peserta didik dapat memberikan tanggapan hasil penjelasan guru tentang FPB dan KPK.

c. Tahap III (Membimbing penyelidikan individual maupun kelompok)

Pada tahap III ini terbukti berhasil, guru dapat mendorong peserta didik untuk mengumpulkan informasi yang sesuai dan melaksanakan ekperimen untuk menyelesaikan suatu masalah. Pada tahap ini peserta didik dapat meyelidiki dan menyelesaikan permasalahan mengenai FPB dan KPK melalui kegiatan individu maupun kelompok.

d. Tahap IV (Mengembangkan dan menyajikan hasil karya) 
Pada tahap IV ini terbukti berhasil, guru membantu peserta didik untuk berbagai tugas dan merencanakan atau menyiapkan karya yang sesuai sebagai hasil pemecahan masalah. Pada tahap ini peserta didik dapat menyampaikan hasil diskusi mengenai pemecahan masalah sehari-hari yang terkait dengan FPB dan KPK.

e. Tahap V (Menganalisis dan mengevaluasi proses pemecahan masalah)

Pada tahap $\mathrm{V}$ ini terbukti berhasil, guru membantu peserta didik untuk melakukan refleksi atau evaluasi terhadap proses pemecahan masalah yang dilakukan. Di tahap ini guru memberikan konfirmasi atau kesimpulan mengenai pembelajaran yang dilakukan oleh peserta didik.

\section{Simpulan dan Saran}

Berdasarkan hasil penelitian yang dilakukan dapat disimpulkan bahwa model pembelajaran Problem Based Learning dengan media DAKOTA efektif terhadap hasil belajar materi FPB dan KPK kelas IV SDN Banyubiru 01 Kabupaten Semarang. Hal ini dapat dilihat dari rata-rata hasil postest lebih tinggi dari pada pretest selain itu diperkuat dengan hasil perhitungan uji t diperoleh thitung untuk hasil belajar sebesar 14,999 dan dan ttabel sebesar 1,684 karena thitung $(14,999)>$ ttabel $(1,684)$ maka hal ini menunjukkan bahwa uji $t$ hasil belajar signifikan.

Dari hasil penelitian, maka saran yang dapat diajukan adalah sebagai berikut : 1) Model pembelajaran Problem Based Learning dengan media DAKOTA dapat meningkatkan hasil belajar siswa, oleh karena itu guru perlu menerapkan model pembelajaran Problem Based Learning dengan media DAKOTA dengan baik agar siswa lebih semangat dan antusias dalam mengikuti proses kegiatan belajar mengajar, 2) Hasil penelitian dapat digunakan sebagai dasar penelitian lanjut.

\section{Daftar Rujukan}

Agustin, Rindu rahayu. 2016. "Media Pemahaman Konsep KPK dan FPB Bagi siswa Kelas IV Sekolah Dasar Berdasarkan Analisis Permainan Congklak". http://repository.upi.edu/22590/. Diakses pada tanggal 13 Oktober 2018 pukul 12:47 AM.

Andesta, Lia. 2017. "Pengaruh Model Pembelajaran Problem Based Learning (PBL) terhadap Hasil Belajar Matematika Peserta Didik di Kelas IV Min 11 Bandar Lampung".

http://repository.radenintan.ac.id/2531/1/skripsi_lengkap_lia.pdf.

Di akses pada tanggal 20 oktober 2018 pukul 12:34 AM.

Arikunto, Suharsimi. 2016. Dasar-Dasar Evaluasi Pendidikan. Jakarta: PT Bumi Aksara

Aqib, Zaenal. 2009. Guru Profesional Berstandar Nasional. Bandung: Yrama Widya

Daryanto.2014. Pembelajaran Tematik, Terpadu, Terintegrasi (Kurikulum 2013). Yogyakarta : GAVA MEDIA.

Fathani, Abdul Halim. 2009. Matematika Hakikat \& Logika. Jogjakarta: AR-RUZZ MEDIA. 
Hidayat,Asep. 2016. "Pengaruh Penggunaan Alat Peraga Dakon Matematika (DAKOTA) terhadap Hasil Belajar Matematika siswa". http://eprints.uny.ac.id/7412/1/p-52.pdf. Diakses pada tanggal 13 Juni 2018 pukul 12:44 AM.

Juanda, Rahmad. 2017. "Pengaruh Model Problem Based Learning Terhadap Hasil Belajar Matematika Siswa Kelas V SDN Gugus Wijayakusuma Ngaliyan Semarang". http://lib.unnes.ac.id/30036/1/1401413624.pdf. Di akses pada tanggal 13 Juni 2018 pukul 12:47 AM

Nuraaini, Fivi.2017. "Penggunaan Model Problem Based Learning(PBL Untuk Meningkatkan Hasil Belalajar IPA Siswa Kelas 5 SD". e-jurnal Mitra Pendidikan. 1(4): 371 372Runtukahu, J.Tombokan dan Selpius Kandou. 2016. Pembelajan Matematika Dasar Bagi Anak Berkesulitan Belajar. Jogjakarta: AR-RUZZ MEDIA

Sani, Ridwan Abdullah. 2015. Pembelajaran Saintifik . Jakarta: PT. Bumi Aksara.

Sari, Anggun Puspita. 2018. "Pengaruh Model Problem Based Learning Berbantu Media Tangram Terhadap Hasil Belajar Siswa Kelas IV SDN 01 Undaan Kidul Kudus". http://library.upgris.ac.id/filedoc/fulltext/tzblv54429ANGGUN\%20PUSPITA\%20SARI\%2 014120287_SKRIPSI.pdf. Diakses pada tanggal 20 Oktober 2018 pukul 12:44 AM.

Slameto. 2010. Belajar dan Faktor-Faktor yang Mempengaruhinya. Jakarta:PT Rineka Cipta.

Soegeng.2006. Dasar-Dasar Penelitian. Semarang : IKIP PGRI PRESS.

2018. Filsafat Pendidikan. Yogyakarta : Magnum Pustaka Utama.

Sudjana.2005.Metode Statistika. Bandung : PT. Tarsito Bandung.

Sudjana, Nana. 2013. Penilaian Hasil Proses Belajar Mengajar. Bandung: PT Remaja Rosdakarya.. 